\title{
廃棄物処理の観点からみたビルの建築設計計画に 関する調查研究
}

\author{
廃棄物の運搬・保管・処理に係わるビルの諸条件の実態
STUDIES ON THE PROPER REFUSE TREATMENT IN BUILDINGS FOR IMPROVEMENT OF BUILDING DESIGN AND PLANNING

Internal conditions of buildings on refuse carriage, storage and treatment

\author{
垂 水弘夫*, 久保猛志**, 酒井健 興*** \\ Hiroo TARUMI, Takeshi KUBO and Takeoki SAKAI
}

\begin{abstract}
The purpose of this study is to present some information about the builing design and planning from the viewpoint of proper refuse treatment, through the questionnaire investigation to buildings maintenance workers.

In this paper, 227 questionnaires about 13 buiding uses were collected from building maintenance companies and were analysed. Consequently, following points of building conditions were clarified quantitatively: 1) floor space for refuse storage, 2) the number of elevators required for refuse carriage, 3 ) treatment equipments installed in buildings.
\end{abstract}

Keywords: refuse treatment, building use, building design and planning 廃棄物処理，建物用途，建築設計・計画

\section{1.はじめに}

本研究では，ヒル内における廃棄物の適切な処理とそ れを可能にする建築設計・計画が今後益々重要になると の認識に立ち，収集・運搬・保管・処理などのビル内廃 棄物に関する一連の作業が円滑に行われるために必要と される設計上の課題および諸条件を明らかにすることを 目的としている。

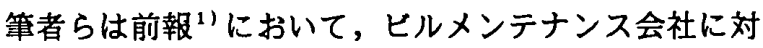
して実施したアンケート調查のうち，建物用途別の廃棄 物排出量および分別収集の実態なと、ビル内廃棄物の発 生と発生段階での分別に関する調查・分析結果を中心に 提示した。

本論文では，アンケート調査の内容のうち建築設計 ・ 計画関連の諸項目，すなわち廃亲物の保管集積のための 所要面積，垂直運搬に多く用いられるエレベーターの使 用台数およひビル内の廃棄物処理設備なとについて建物 用途や規模などの面から解析した結果を中心に提示する
とともに，ヒルメンテナンス従業員のビルの設計に対す る要望事項についても建物用途に従い整理する。

なお，アンケート調查の内容および本研究に関連する 既往の研究・文献については既報 ${ }^{12}{ }^{2)}$ に詳しいか，分析 に供している回答は 13 の建物用途の延床面積 $3000 \mathrm{~m}^{2}$ 以上 のビルから得られた227件である。

\section{2.ビルの各階における一時こみ置場について}

図 1 は，一時こみ置場の調查対象建物における現在の 設置状況とビルメンテナンス従業員が希望する設置形態 を建物用途別に表したものである。まず現在の設置状況 についてみると，全建物用途では「各階にある」割合は $32 \%$ ，「各階にはないか，何ヶ所かある」の19\%を加 えてようやく半数に達している。「各階にある」割合か 高い建物用途は，「百貨店・大型物品販売」（50\%）， 「一般事務所：商社」(44\%)，「一般事務所 : 報道」 （42\%）などであり，このうち「百貨店・大型物品販売」
* 金沢工業大学環境システム工学科 助教授・ 工博

** 金沢工業大学環境システム工学科 教授・ 工博

*** 金沢工業大学大学院建築学専攻 大学院生
Assoc. Prof., Dept. of Enviromental System Engineering, Kanazawa Institute of Technology, Dr. Eng.

Prof., Dept. of Environmental System Engineering, Kanazawa Institute of Technology, Dr. Eng.

Graduate Student, Dept. of Architecture, Kanazawa Institute of Technology 
と「一般事務所：報道」は，廃棄物発生原単位か各々， $146.9 ， 70.4 \mathrm{~g} / \mathrm{m}^{2} \cdot$ 日 $^{1)}$ と大きな建物用途でもある。一方， 「各階にある」割合が低い建物用途は，「一般事務所 : コンピューターセンター」(19\%)，「劇場・ホール・ 集会場」 $(21 \%) ， 「$ 宿泊施設」（24\%）なとである。 次に，希望する設置形態についてみると，全建物用途 では「各階にある方が良い」が53\%を占め，「一時こみ 置場は必要なく，最終集積所のみで十分」の $43 \%$ をゃや 上回った。「各階にある方が良い」との回答割合の高い 建物用途としては，「一般事務所：商社」（78\%）， 「一般事務所：報道」（67\%），「百貨店 - 大型物品販 売」（65\%）などか上位にあり，これらは現在の設置状 況として「各階にある」割合の高い建物用途と合致する。 また，ほとんとの建物用途において「各階にある方が良 い」とする回答か，「一時こみ置場は必要なく，最終集 積所のみで十分」とする回答を上回る中で，逆の傾向を
示したのか「劇場・ホール・集会場」と「一般事務所 : コンピューターセンター」の 2 つの建物用途であった。 この原因としては，「劇場・ホール・集会場」の場合に は建物自体が低層階の大空間から構成されていること， また，「一般事務所 : コンピューターセンター」の場合 には廃棄物発生原単位に占めるOA用紙の割合か $30 \%$ と 全建物用途中で最も高く" ${ }^{11}$ ，その回收容器がプリンター など出力装置の周辺に予め設置されていること, などか 考えられる。

ビルの基準階面積ランクに従って表した一時こみ置場 の現在の設置状況と希望する設置形態を図 2 に示す。希 望する設置形態として「各階にある方が良い」割合は， 基準階面積が $1000 \mathrm{~m}^{2}$ 末満のビルでは $47 \%$ と半数に満たな いか， 5000m²以上では76\%に達している。

図 1 およひ図 2 中で，希望する設置形態の欄にみられ る「その他」の内容は，各階になくても何ヶ所かあれば

\begin{tabular}{|c|c|c|c|}
\hline & 回答数 & 現在の設置状況（\%） & 希望する設置形態（\%） \\
\hline 全建物用途 & 212 & 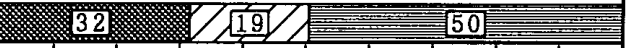 & $43 \sqrt{15}$ \\
\hline 一般事務所：その他一般 & 62 & 15. & (44) \\
\hline 一般事務所 :コンヒューターセンター & 21 & $19 \times \sqrt{24}$ & 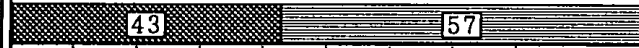 \\
\hline 一般事務所：金蛬 & 15 & 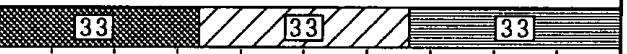 & 33 \\
\hline 一般事務所：報道（電波） & 12 & 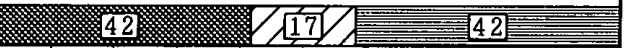 & 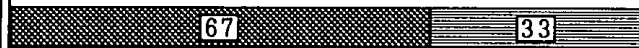 \\
\hline 一般事務所：商社 & 9 & (11) & 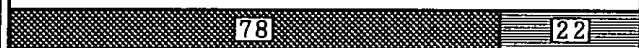 \\
\hline 一般事務所：出版 & 8 & 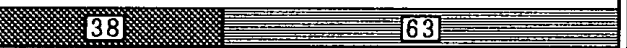 & 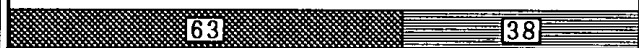 \\
\hline 宿泊施設 & 21 & 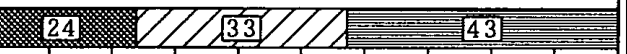 & 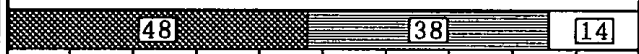 \\
\hline 百貨店 $\cdot$ 大型物品販売 & 20 & $715 / 2$ & 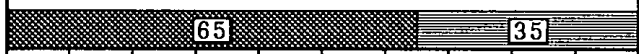 \\
\hline 劇場・ホール・集会場 & 19 . & $21) / \sqrt{16} / /$ & 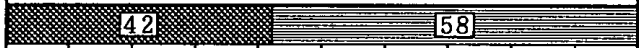 \\
\hline 教育施設 & 16 & 50 & 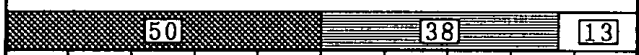 \\
\hline & & $\begin{array}{l}\text { 各陵にある } \\
\text { 各階にはないが、何ヶ所かある } \\
\text { ない }\end{array}$ & $\begin{array}{l}\text { 各椙にある方が良い } \\
\text { 一時こみ㯰場は必要なく、最終集樌所のみで十分 } \\
\text { その他 }\end{array}$ \\
\hline
\end{tabular}

図 1 一時ごみ㯰場に関する現在の設置状況とビルメンテナンス従業員の希望する設置形態（建物用途別）

\begin{tabular}{|c|c|c|c|}
\hline 基準階面糟 $\left(\mathrm{m}^{2}\right)$ & 回答敖 & 現在の設圈状況（\%） & 希望する設置形態（\%） \\
\hline $\begin{aligned} \text { (以上) } & \text { (未渵) } \\
\sim & 1000\end{aligned}$ & 78 & 211 $/ / 21 / 2$ & 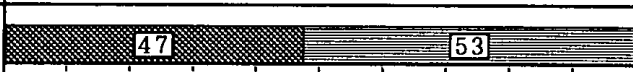 \\
\hline $1000 \sim 2000$ & 61 & 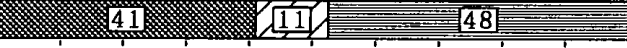 & 对: \\
\hline $2000 \sim 5000$ & 55 & 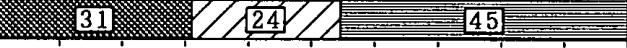 & 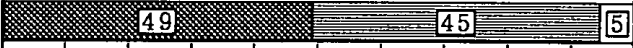 \\
\hline $5000 \sim$ & 17 & 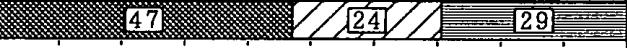 & 18高娄 \\
\hline & & $\begin{array}{l}\text { 各階にある } \\
\text { 各にはないが、何ケ所かある } \\
\text { ない }\end{array}$ & $\begin{array}{l}\text { 各階にある方が良い } \\
\text { 二時こみ置場は必要なく、最終集䅡所のみで十分 } \\
\text { その他 }\end{array}$ \\
\hline
\end{tabular}

図 2 一時こみ置場に関する現在の設置状況とビルメンテナンス従業貣の希望する設置形態（基準階面積ランク別） 
表 1 一時こみ置場面積の基準階面積に占める割合 (単位 : \%)

\begin{tabular}{|c|c|c|c|c|c|c|c|}
\hline \multirow{2}{*}{ 建物用途 } & \multirow{2}{*}{ 平均値 } & \multicolumn{6}{|c|}{ 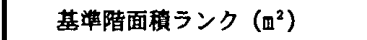 } \\
\hline & & $\sim 10$ & \begin{tabular}{r|r}
00 & $1000-20$ \\
\end{tabular} & $\tilde{0}^{2}$ & $\begin{array}{r}2000 \sim \\
500\end{array}$ & 5000 - & \\
\hline 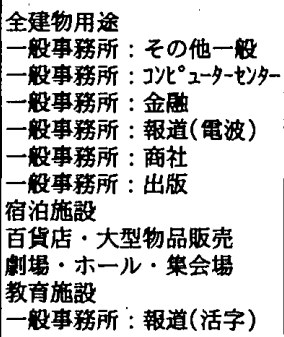 & \begin{tabular}{l|l}
0.28 & 7 \\
0.33 & 2 \\
0.19 & \\
0.19 & \\
0.32 & \\
0.23 & \\
0.14 & \\
0.65 & \\
0.17 & \\
0.14 & \\
0.17 & \\
0.61 &
\end{tabular} & $\mid \begin{array}{c}0.49 \\
0.63 \\
0.15 \\
0.26 \\
\overline{0} \\
0.22 \\
\overline{0} \\
- \\
\overline{-} \\
0.10 \\
-\end{array}$ & \begin{tabular}{r|l|}
19 & 0.25 \\
8 & 0.11 \\
1 & 0.34 \\
3 & 0.19 \\
0 & 0.41 \\
2 & 0.24 \\
0 & 0.14 \\
4 & 0.56 \\
0 & 0.44 \\
0 & 0.11 \\
1 & 0.20 \\
0 & 0.61
\end{tabular} & \begin{tabular}{r|r}
27 & 0 \\
9 & 0 \\
2 & 0 \\
1 & 0 \\
3 & 0 \\
2 & \\
2 & \\
2 & \\
2 & 0 \\
2 & 0 \\
1 & 0 \\
1 &
\end{tabular} & $\begin{array}{l}.14 \\
.19 \\
07 \\
13 \\
.08 \\
- \\
- \\
-11 \\
.11 \\
.21 \\
.19 \\
-\end{array}$ & \begin{tabular}{|c|c|}
7 & 0.16 \\
3 & 0.33 \\
2 & - \\
3 & - \\
1 & - \\
0 & - \\
0 & $=$ \\
0 & - \\
4 & 0.08 \\
2 & 0.06 \\
2 & 0.16 \\
0 & -
\end{tabular} & \\
\hline
\end{tabular}

* 各唡の右僛の数值は回答数。

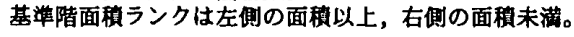

表 2 一時こみ置場面積の延床面積に占める割合 (ビル内の廃棄物分別種類数別)

\begin{tabular}{|c|c|c|c|c|c|}
\hline \multirow{2}{*}{ 分別種類数 } & \multirow{2}{*}{ 平均值 } & \multicolumn{4}{|c|}{ 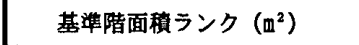 } \\
\hline & & $\sim 1000$ & $\begin{array}{r}1000 \sim \\
2000\end{array}$ & $\begin{array}{r}2000 \sim \\
5000\end{array}$ & $5000 \sim$ \\
\hline $\begin{array}{l}\text { 全体 } \\
4 \text { 種類以下 } \\
5 \text { 種類以上 }\end{array}$ & \begin{tabular}{l|l}
0.28 & 70 \\
0.20 & 20 \\
0.31 & 50
\end{tabular} & $\left\{\begin{array}{r|r}0.49 & 19 \\
0.24 & 4 \\
0.55 & 15\end{array}\right.$ & \begin{tabular}{|r|r}
0.25 & 27 \\
0.24 & 8 \\
0.26 & 19
\end{tabular} & \begin{tabular}{|r|r|}
0.14 & 17 \\
0.13 & 6 \\
0.15 & 11 \\
\end{tabular} & \begin{tabular}{|l|l}
0.16 & 7 \\
0.13 & 2 \\
0.17 & 5
\end{tabular} \\
\hline
\end{tabular}

* 、各榴の右㑡の数值は回答数。

延床面䅡ランクは左倒の面樻以上，右倒の面稘末满。

良いとするものや，ビルの現状に照らして各階への設置 は無理とするものなどでった。

表 1 は，各階の一時こみ置場の面積は1)の基準階面積 に占める割合を，建物用途別の平均と基準階面積ランク ことの内訳の平均として示したものである。全建物用途 に関する70件の回答の平均は $0.28 \%$ あった。「宿泊施 設」の $0.65 \%$ が大きく，一方，「劇場・ホール・集会場」 の0.14\%が小さな值である。また, 基準階面積ランクに 従った結果からは，必ずしもランク分けに十分な回答数 が得られてはいないものの, 基準階面積の小さなビルに おける一時こみ置場ほど, この割合が多くの建物用途に おいて大きくなる様子がみられる。

さらに表 2 は，ビル内で分別されている廃棄物の種類 数をもとに，各階の一時こみ置場の面積の基準階面積に 占める割合を調べた結果である。一時ごみ置場の所要面 積に関連が大きい廃棄物として資源こみの紙類，ビンお よび缶と, 可燃物, 不燃物の計 5 種類を想定し, 「4 種 類以下」と「5種類以上」に区分した。「5種類以上」 の分別を実施しているビルおける数值の方が，「4 種 類以下」のビルの数值よりも平均值および各基準階面積 ランクを通じて高くなっている様子がみられ，分別の実 施の程度と一時こみ置場の所要面積との関連性の高さか 認められたものと理解される。

\section{3.廃棄物のビル内垂直運搬と処理設備について}

廃棄物の垂直運搬設備であるエレベーターの利用状況 について，建物用途別の結果を図 3 に，また延床面積 ンクによる結果を図 4 に示す。全建物用途では，「荷物 用エレベーターのみ利用」が51\%を占め，「一般用エレ ベーターのみ利用」の39\%を上回っている。「荷物用エ レベーターのみ利用」の割合が高い建物用途としては，

「百貨店・大型物品販売」 $(79 \%) ， 「 一$ 般事務所 : コ ンピューターセンター」（67\%），「宿泊施設」（64\%） などがあ，一方，「一般用エレベーターのみ利用」の 割合が高いのは，「教育施設」(73\%)，「一般事務所 : 報道（電波）」（60\%），「劇場・ホール・集会場」 （56\%）なとととなっている。「荷物用と一般用エレベー

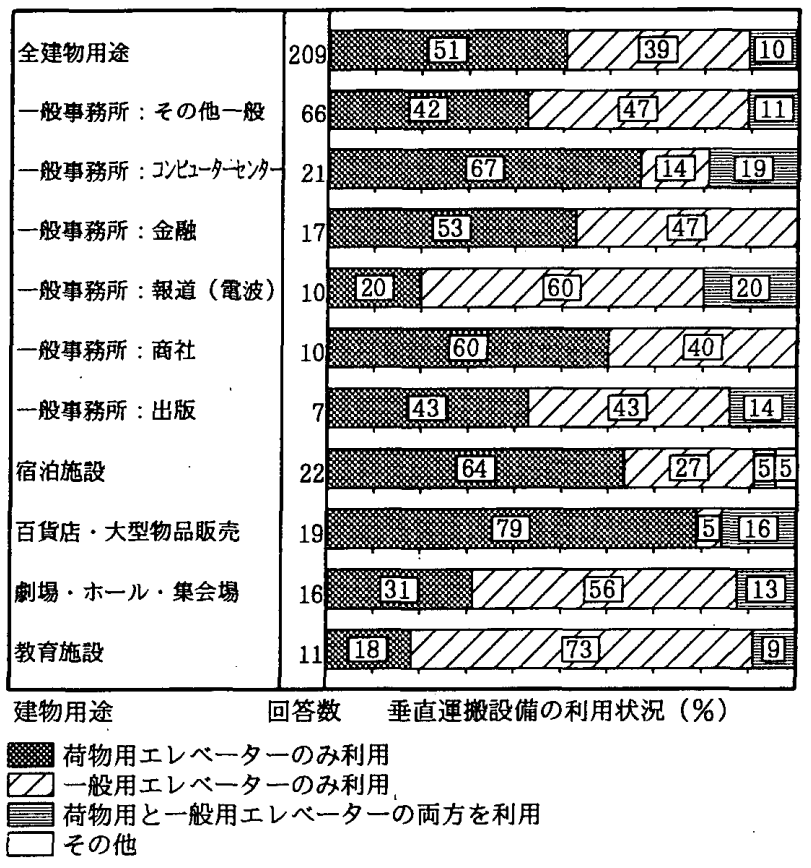

図 3 廃棄物の垂直運搬に使用されているエレベーター の使用状況（建物用途別）

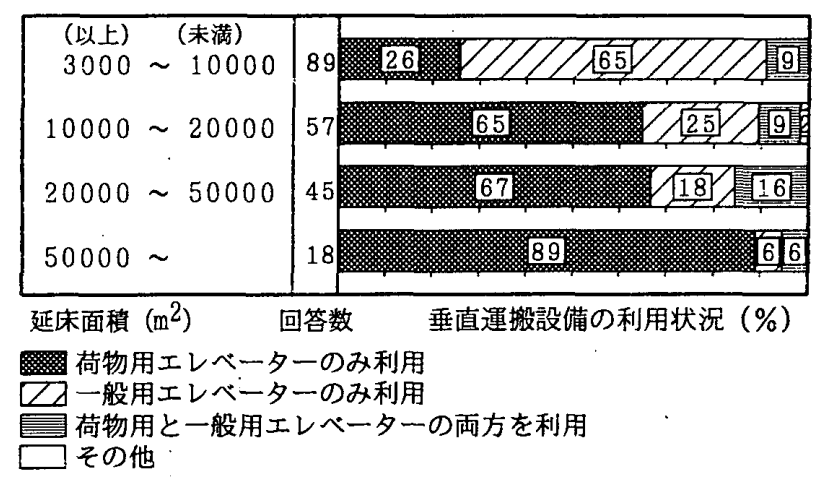

図4廃棄物の垂直運搬に使用されているエレベーター の使用状況（延床面積ランク別） 
ターの両方を利用」している割合は，高くても「一般事 務所：報道（電波）」の20\%，「一般事務所 : コンピュ ーターセンター」の19\%程度であるか，この 2 つの建物 用途では両方を利用している意味合いが異なり，上述し たことく「一般事務所 : 報道（電波）」では「一般用エ レベーターのみ利用」の割合が高い中での両方利用，

「一般事務所 : コンピューターセンター」では「荷物用 エレベーターのみ利用」の割合が高い中での両方利用と なっている。

延床面樌ランクに従ったエレベーターの利用状況とし ては，大規模なヒルほと「荷物用エレベーターのみ利用」 の割合が高まる傾向が明確に示されている。すなわち， $3000 \mathrm{~m}^{2}$ 以上 $10000 \mathrm{~m}^{2}$ 未満のビルでは $26 \%$ に留まっている のに対し，50000m²以では $89 \%$ に達している。

表 3 および表 4 には，廃棄物の運搬に使用されている 平均エレベータ一台数をまとめた。全建物用途について みると，「荷物用エレベーターのみ利用」の場合は 1.6 台，「一般用エレベーターのみ利用」の場合は1.9台， 両方利用の場合は荷物用が1.4台で一般用が2.2台という 結果となっている。予想されるように「荷物用エレベー ターのみ利用」の場合が最も使用台数が少なく，この傾 向はほとんとの建物用途においてもみられる。「荷物用 エレベーターのみ利用」の使用台数が多い建物用途とし ては，「宿泊施設」（3.0台），「百貨店 -大型物品販 売」（1.9台）なとが挙げられる。

延床面積ランク別の結果からは, 面積の增大に伴う使 用エレベーター台数の増加を読み取ることが可能である。 また，50000m² 以上の面積ランクにおける「一般用エレ ベーターのみ利用」の欄に11.0台と示されているのは，
このような運用を行っている宿泊施設の例があるためで ある。

次に，ビルに設置されている廃棄物処理設備について， 現状としての設置数およびビルメンテナンス従業員が今 後設置を希望する数を，処理設備の種類および建物用途

表 3 廃棄物の垂直運搬に使用されている建物用途別 平均エレベーター台数*

\begin{tabular}{|c|c|c|c|c|c|c|}
\hline 建物用途 & \multicolumn{2}{|c|}{$\begin{array}{l}\text { 荷物用のみ } \\
\text { 利用 }\end{array}$} & \multicolumn{2}{|c|}{\begin{tabular}{|l} 
一般用のみ \\
利用
\end{tabular}} & \multicolumn{2}{|c|}{$\begin{array}{c}\text { 両方利用 } \\
\text { (荷物用+一般用) }\end{array}$} \\
\hline 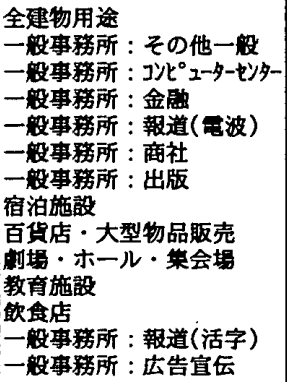 & $\begin{array}{l}1.6 \\
1.3 \\
1.3 \\
1.1 \\
1.0 \\
1.2 \\
1.0 \\
3.0 \\
1.9 \\
1.4 \\
1.0 \\
1.0 \\
1.3 \\
1.0\end{array}$ & $\begin{array}{r}107 \\
28 \\
14 \\
9 \\
2 \\
6 \\
3 \\
14 \\
16 \\
5 \\
2\end{array}$ & $\begin{array}{l}1.9 \\
1.9 \\
1.3 \\
2.0 \\
1.5 \\
1.3 \\
2.0 \\
3.5 \\
2.0 \\
1.3 \\
1.9 \\
1.0 \\
1.0\end{array}$ & \begin{tabular}{r|}
81 \\
31 \\
3 \\
8 \\
6 \\
4 \\
3 \\
6 \\
1 \\
9 \\
8 \\
1 \\
0 \\
1
\end{tabular} & $\begin{array}{r}1.4+2.2 \\
1.1+2.3 \\
1.5+1.8 \\
1.0+5.5 \\
1.0+2.0 \\
1.0+1.0 \\
2.7+1.7 \\
1.0+1.5 \\
1.0+1.0\end{array}$ & 21 \\
\hline
\end{tabular}

* 各桶の左㑡の数值がエレベーター台数，右側の数值は回答数。 回答数が 1 件の掦合も参考として台数を示している。

表 4 廃棄物の垂直運搬に使用されている延床面積 ランク別平均エレベーター台数*

\begin{tabular}{|c|c|c|c|c|c|c|}
\hline $\begin{array}{ll}\text { 延床面積ランク } & \left(\mathrm{m}^{2}\right) \\
\text { (以上) } & \text { (末满) }\end{array}$ & \multicolumn{2}{|c|}{$\begin{array}{l}\text { 荷物用のみ } \\
\text { 利用 }\end{array}$} & \multicolumn{2}{|c|}{$\begin{array}{l}\text { 一般用のみ } \\
\text { 利用 }\end{array}$} & \multicolumn{2}{|c|}{$\begin{array}{c}\text { 雨方利用 } \\
\text { (何物用+一般用) }\end{array}$} \\
\hline 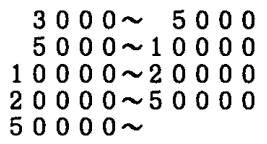 & $\begin{array}{l}1.0 \\
1.0 \\
1.1 \\
1.6\end{array}$ & $\begin{array}{r}7 \\
16 \\
37 \\
30\end{array}$ & $\begin{array}{l}1.4 \\
1.7 \\
2.1 \\
2.4 \\
11.0\end{array}$ & $\begin{array}{r}25 \\
33 \\
14\end{array}$ & $\begin{array}{l}1 . \\
1 . \\
1 . \\
1 . \\
5 .\end{array}$ & \\
\hline
\end{tabular}

* 各柯の左側の数值がエレベーター台数, 右側の数值は回答数。 回答数が 1 件の措合も考として台数を示している。

表 5 廃棄物処理設備の建物用途別設置数と今後の設置希望数*

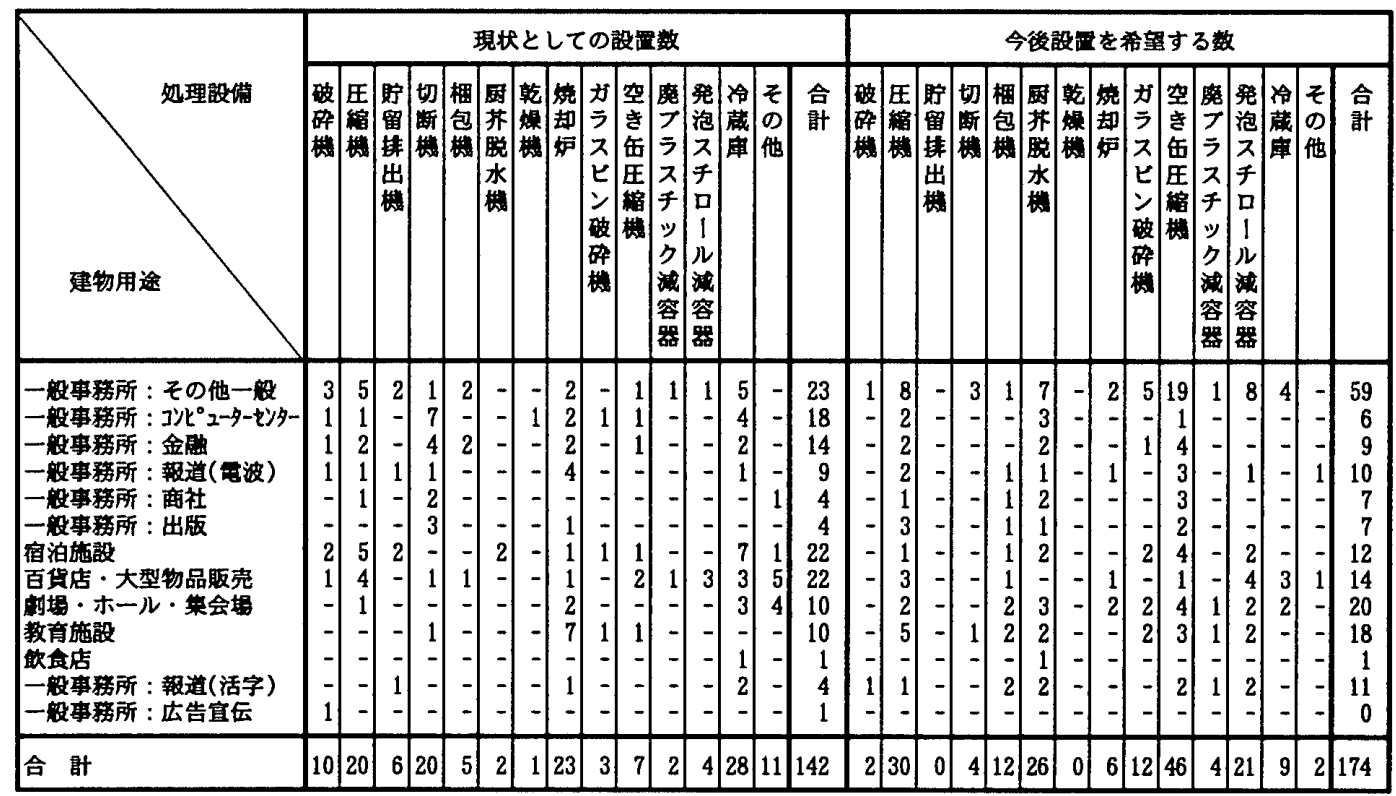

* 設借の台数ではなく，設需の有艮を表す件数である。 
別に表 5 に整理した。現状として設置数の多い処理設備 は「冷蔵庫」（28件），「焼却炉」（23件），「圧縮機」 (20件)，「切断機」（20件）などであり，建物用途別 にみると，「一般事務所 : コンピューターセンター」に おける「切断機」（7件），「宿泊施設」における「冷 蔵庫」（7件）なとかか目立つ。

一方，今後設置を希望する設備としては，「空き缶圧 縮機」（46件），「圧縮機」（30件），「四芥脱水機」

（26件），「発泡スチロール減容器」（21件）なと，廃 棄物の減容化・減量化に関連する設備に回答が集中する 結果となった。

\section{4. 廃棄物の最終集樌所について}

図 5 は，ヒルの延床面積と最終集積所面積との散布図 である。全建物用途に関する相関係数は $0.42 に$ 留まって いる。そこで，各建物用途ことに相関係数と回帰式を求 め，表6にまとめた。「一般事務所：報道（電波）」， 「一般事務所：商社」および「一般事務所：金融」なと で相関係数 $0.87 \sim 0.83$ 程度の関係が得られているものの， 既報”に示した収集面積と廃棄物排出量の場合ほと，建 物用途別の分析の実施によって相関係数が軒並上昇する というような様子はみられない。

この原因としては，表 7 に示されているようにヒルに よって廃棄物の搬出頻度が異なっている点の他, 所要面 積の設計基準が明確にされていないこど)，後揭のビル メンテナンス従業員の記述意見（表11）にもみられるよ うに，設計段階における最終集積所の優先順位の低さや， 場合によっては設計に含まれていないという実態，なと が考えられる。

既報 ${ }^{2}$ では，一般事務所ヒルという単一の建物用途と して158件の回答を集め分析を行ったため, 最終集積所 面積の延床面積に占める割合の提示にあたっては，資源 こみ置場をはじめとする $5 つ$ の置場の種類ことに搬出頻 度を考虑し, さらに, ビルメンテナンス従業員の広さの 評価ランク別に数值を示すことか可能であった。しかし， 本論文では建物用途別の調查分析を主眼として，各建物 用途ことに 10 棟以上の回収を目標にアンケート調查 ${ }^{1 !}$ 実施しており，上述したような細分類に堪えるだけの建 物用途別回答数は確保されていない。

そこで，本論文では最終集積所面積到 の延床面積に占 める割合を，建物用途別の平均と延床面積ランクことの 内訳の平均として表 8 に示した。「一般事務所 : 出版」 の0.83\%が最も大きく、これに「教育施設」の0.55\%， 「一般事務所 : コンピューターセンター」の $0.49 \%$ なと が続いている。一方，この割合が小さいのは「一般事務 所：報道（活字）」の0.14\%，「一般事務所：金䃒」の $0.17 \%$ などある。

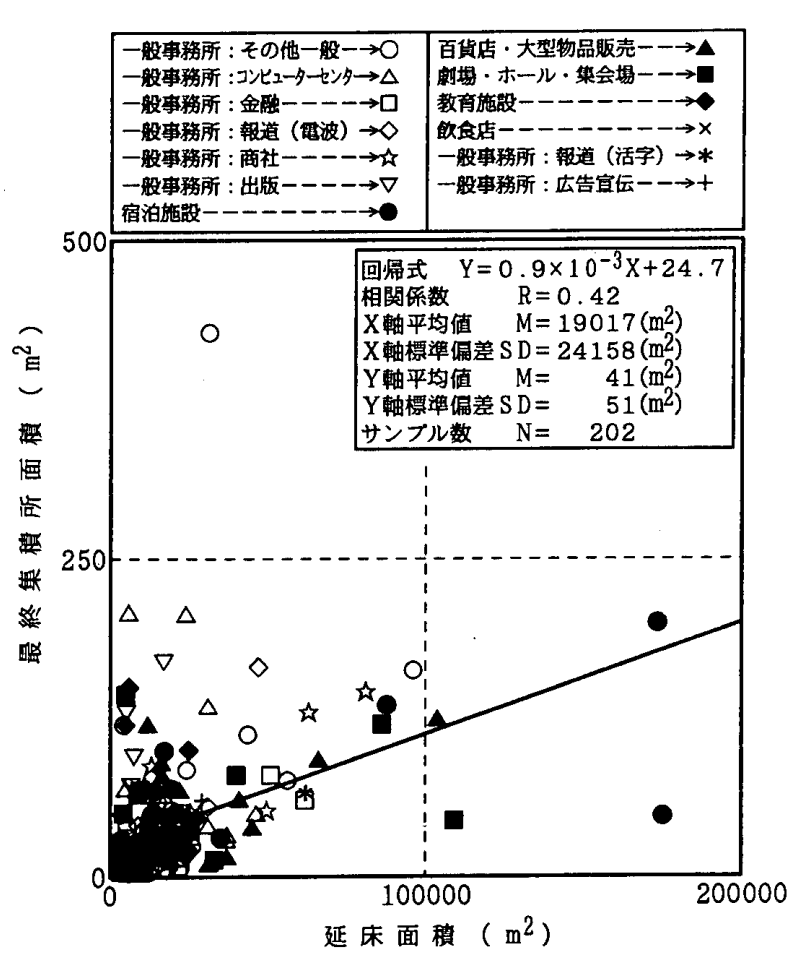

図 5 延床面積と最終集積所面積との関係

表 6 延床面積と最終集積所面積の相関（建物用途別）

\begin{tabular}{|c|c|c|c|}
\hline 建物用途 & 相開係数 & 回 州 式 & 回答数 \\
\hline 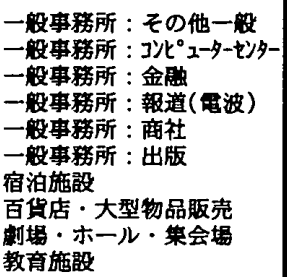 & $\begin{array}{l}0.49 \\
0.12 \\
0.83 \\
0.87 \\
0.87 \\
0.16 \\
0.67 \\
0.48 \\
0.31 \\
0.17\end{array}$ & $\begin{array}{l}Y=0.0020 X+2 \\
Y=0.0006 X+46 \\
Y=0.0011 X+5 \\
Y=0.0029 X+1 \\
Y=0.0017 X+7 \\
Y=0.0017 X+52 \\
Y=0.0006 X+26 \\
Y=0.0007 X+36 \\
Y=0.0004 X+32 \\
Y=0.0009 X+30\end{array}$ & $\begin{array}{r}59 \\
20 \\
13 \\
12 \\
10 \\
8 \\
19 \\
17 \\
18 \\
16\end{array}$ \\
\hline
\end{tabular}

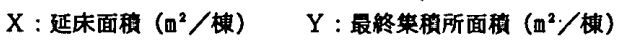

表 7 最終集積所からの廃棄物搬出回数別の回答内訳*

\begin{tabular}{|c|c|c|c|c|c|c|c|c|c|}
\hline \multirow{2}{*}{ 種別 } & \multirow{2}{*}{ 临 } & \multirow{2}{*}{\begin{tabular}{|l} 
日回数 \\
2目以上 1 回 \\
\end{tabular}} & \multicolumn{6}{|c|}{ 週間回数 } & 月間回数 \\
\hline & & & & 5 目 & 4 的 & 3日 & 2日 & 19 & 3日 $\quad 2$ 回 1 日 \\
\hline \multirow{2}{*}{ 资源こみ置場 } & \multirow{2}{*}{182} & 850 & 3 & 3 & 1 & 9 & 19 & 44 & $\begin{array}{lll}3 & 14 & 28\end{array}$ \\
\hline & & $4 \% 27 \%$ & $2 \%$ & $2 \%$ & $1 \%$ & $5 \%$ & $10 \% 2$ & & $2 \% \quad 8 \% \quad 15 \%$ \\
\hline \multirow{2}{*}{ 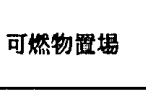 } & \multirow{2}{*}{197} & 13121 & 8 & 6 & - & 22 & 14 & 10 & -21 \\
\hline & & $7 \% 61 \%$ & $4 \%$ & $3 \%$ & $0 \% 1$ & $11 \%$ & $7 \%$ & $5 \%$ & $\begin{array}{lll}0 \% & 1 \% & 1 \%\end{array}$ \\
\hline \multirow{2}{*}{ 不燃物罟埸 } & \multirow{2}{*}{179} & $\begin{array}{ll}6 & 53 \\
\end{array}$ & & 1 & - & 12 & 35 & & $\begin{array}{lll}4 & 5 & 19\end{array}$ \\
\hline & & $3 \% 30 \%$ & $2 \%$ & $1 \%$ & $0 \%$ & $7 \%$ & $20 \% 2$ & & $2 \% \quad 3 \% \quad 11 \%$ \\
\hline \multirow{2}{*}{ 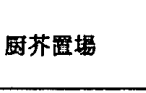 } & \multirow{2}{*}{183} & 9120 & 6 & 5 & - & 18 & 15 & 9 & $-\quad-1$ \\
\hline & & $5 \% 66 \%$ & $3 \%$ & $3 \%$ & $0 \% 1$ & $10 \%$ & $8 \%$ & $5 \%$ & $\begin{array}{llll}0 \% & 0 \% & 1 \%\end{array}$ \\
\hline \multirow{2}{*}{ 相大こみ置場 } & \multirow{2}{*}{105} & 19 & - & 1 & - & 3 & 1 & & -966 \\
\hline & & $18 \quad 9 \%$ & $0 \%$ & $1 \%$ & $0 \%$ & $3 \%$ & $1 \% 1$ & & $0 \% \quad 9 \% 63 \%$ \\
\hline
\end{tabular}

* 上段は内訳としての回答数、下段は回答総数に対する割合 
延床面積ランクによる結果からは, 一時ご置場面積 の場合（表 1 ）と同様に，延床面積が小さくなるほどこ の割合が大きくなる傾向がみられる。

既報 ${ }^{2}$ に示した建物用途を特定しない一般事務所ビル の場合の割合は0.65\%となっており，これと比較して本 論文の調査結果における一般事務所の各建物用途の值は, 「一般事務所：出版」の0.83\%を除き，低い数值である。 既報 ${ }^{2}$ では，5種類の置場ことと面積を積み上げて最終 集積所面積を求めたのに対し，本論文の調査対象とした ヒルでは各置場が明確に仕切られているものが少なく， 最終集積所全体の面積として算定したことにこの原因が あるものと考えられる。表 9 には各置場面積が明らかな ビルか 3 件以上把握された建物用途について，その平均 としての面積割合を示す。

表 8 最終集積所面積の延床面積に占める割合

\begin{tabular}{|c|c|c|c|c|c|c|c|c|}
\hline \multirow{2}{*}{ 建物用途 } & \multirow{2}{*}{\multicolumn{2}{|c|}{ 平为值 }} & \multicolumn{6}{|c|}{ 延床面稓ランク（郋） } \\
\hline & & & $\sim 10000$ & $\begin{array}{r}10000 \\
2000\end{array}$ & \begin{tabular}{r|r}
$\tilde{1} \tilde{0} \tilde{0}$ & 200 \\
\end{tabular} & $\begin{array}{r}0000 \sim \\
50000\end{array}$ & 50000 & \\
\hline 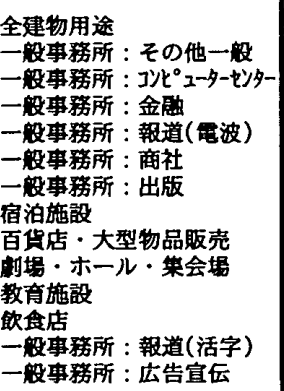 & $\begin{array}{l}0.34 \\
0.25 \\
0.49 \\
0.17 \\
0.37 \\
0.23 \\
0.83 \\
0.27 \\
0.28 \\
0.43 \\
0.55 \\
0.21 \\
0.14 \\
0.19\end{array}$ & $\begin{array}{r}202 \\
59 \\
20 \\
13 \\
12 \\
10 \\
8 \\
19 \\
17 \\
18 \\
16 \\
4 \\
4 \\
2\end{array}$ & \begin{tabular}{|l|l}
0.47 & 93 \\
0.31 & 28 \\
0.79 & 8 \\
0.24 & 5 \\
0.46 & 7 \\
0.21 & 5 \\
1.04 & 5 \\
0.38 & 6 \\
0.29 & 2 \\
0.63 & 11 \\
0.69 & 11 \\
0.21 & 4 \\
0.17 & 1 \\
0.17 & 1
\end{tabular} & \begin{tabular}{l|l|l}
3 & 0.27 & 5 \\
8 & 0.16 & 1 \\
8 & 0.32 & \\
5 & 0.13 & \\
7 & 0.21 \\
5 & 0.40 \\
5 & 0.48 \\
6 & 0.34 & \\
2 & 0.45 & \\
1 & 0.13 & \\
1 & 0.28 \\
4 & - \\
0 & 0.11 & \\
1 & -
\end{tabular} & \begin{tabular}{r|l}
52 & 0.2 \\
18 & 0.2 \\
5 & 0.2 \\
2 & 0.1 \\
3 & 0.2 \\
2 & 0.1 \\
3 & \\
6 & 0.1 \\
7 & 0.1 \\
2 & 0.1 \\
2 & 0.2 \\
0 & \\
2 & 0.2 \\
0 & 0.2
\end{tabular} & \begin{tabular}{l|l}
.20 & 43 \\
.25 & 11 \\
.27 & 7 \\
.11 & 4 \\
.27 & 2 \\
.11 & 1 \\
.14 & 0 \\
.14 & 6 \\
.13 & 3 \\
.22 & 3 \\
- & 0 \\
.24 & 0 \\
.21 & 1
\end{tabular} & $\left|\begin{array}{c}0.13 \\
0.15 \\
-\overline{1} \\
0.13 \\
-1 \\
0.19 \\
-\overline{10} \\
0.13 \\
0.09 \\
- \\
- \\
0.11 \\
-\end{array}\right|$ & \begin{tabular}{r|r}
14 \\
2 \\
0 \\
2 \\
0 \\
2 \\
0 \\
3 \\
2 \\
2 \\
0 \\
0 \\
1 \\
0
\end{tabular} \\
\hline
\end{tabular}

* 各相の右側の数值は回答数。

延床面箖ランクは左例の面稓以上，右㑡の面稹末满。

表 9 最終集積所面積の置場別内訳

（単位 : \%)

\begin{tabular}{|c|c|c|c|c|c|c|}
\hline 建物用途 & $\begin{array}{l}\text { 件 } \\
\text { 数 }\end{array}$ & $\begin{array}{l}\text { 资源こ } \\
\text { み畋域 }\end{array}$ & $\begin{array}{c}\text { 可嬁物 } \\
\text { 置埸 }\end{array}$ & $\begin{array}{c}\text { 不然物 } \\
\text { 睥场 }\end{array}$ & $\begin{array}{l}\text { 爵苏 } \\
\text { 蜀場 }\end{array}$ & $\begin{array}{l}\text { 粗大こ } \\
\text { み置堨 }\end{array}$ \\
\hline 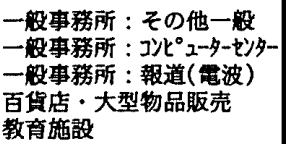 & $\begin{array}{r}18 \\
4 \\
4 \\
3 \\
3\end{array}$ & $\begin{array}{lll}2 & 2 & \% \\
2 & 0 & \% \\
2 & 2 & \% \\
2 & 2 & \% \\
1 & 9 & \%\end{array}$ & $\begin{array}{lll}2 & 2 & \% \\
3 & 2 & \% \\
3 & 5 & \% \\
1 & 9 & \% \\
1 & 9 & \%\end{array}$ & $\begin{array}{lll}2 & 2 & \% \\
1 & 1 & \% \\
2 & 0 & \% \\
1 & 8 & \% \\
1 & 5 & \%\end{array}$ & $\begin{array}{l}14 \% \\
15 \% \\
7 \% \\
15 \% \\
11 \%\end{array}$ & $\begin{array}{l}20 \% \\
22 \% \\
17 \% \\
26 \% \\
36 \%\end{array}$ \\
\hline
\end{tabular}

表10 最終集積所面積の延休面積に占める割合 （ビル内の廃棄物分別種類数別）

(単位 : \%)

\begin{tabular}{|c|c|c|c|c|c|c|c|}
\hline \multirow{2}{*}{ 分別種類数 } & \multirow{2}{*}{\multicolumn{2}{|c|}{ 平均值 }} & \multicolumn{5}{|c|}{ 延床面稹ランク $\left(\mathbf{m}^{2}\right)$} \\
\hline & & & $\sim 10000$ & $\begin{array}{r}10000 \sim \\
20000\end{array}$ & $\begin{array}{r}20000 \\
500\end{array}$ & $10 \sim$ & $50000 \sim$ \\
\hline $\begin{array}{l}\text { 全体 } \\
4 \text { 種類以下 } \\
5 \text { 種類以上 }\end{array}$ & $\begin{array}{l}0.34 \\
0.35 \\
0.33\end{array}$ & $\begin{array}{r}202 \\
40 \\
162\end{array}$ & \begin{tabular}{|l|l}
0.47 & 93 \\
0.45 & 27 \\
0.48 & 66
\end{tabular} & \begin{tabular}{|l|r}
0.27 & 52 \\
0.14 & 5 \\
0.28 & 47
\end{tabular} & $\begin{array}{l}0.20 \\
0.16 \\
0.20\end{array}$ & $\begin{array}{r}43 \\
6 \\
37\end{array}$ & \begin{tabular}{|r|r}
0.13 & 14 \\
0.15 & 2 \\
0.12 & 12
\end{tabular} \\
\hline
\end{tabular}

* 各橍の右側の数值は回答数。

延床面稳ランクは左側の面樌以上，右側の面樌未满。
表10は，ビル内で分別されている廃棄物の種類数をも とに，最終集積所面積の延床面積に占める割合を示した ものである。表 9 の 5 つの置場を想定し，「4 種類以下」 と「5種類以上」に区分した。結果をみると $50000 \mathrm{~m}^{2}$ 末 満までの延床面積ランクでは「5種類以上」のビルの数 值の方がやや高目となっているものの，一時ご置場の 場合（表 2 ）と比較すると，両者の相異はほとんと認め られない程度の僅かなものと云える。このことは，ビル 廃棄物に関する分別実施の普及・要求に対して一時ごみ 置場よりも最終集積所の面積確保の方が難しい点を反映 しているとも考えられ，余裕を持った設計の必要性が認 識される。

図 6 および図 7 は，最終集積所の屋内・屋外設置の別 とそこへの収集車の出入りの可能・不可能を，建物用途 および延床面積ランクに従って分類したものである。全 建物用途では屋内設置の割合は61\%，収集車の出入りか 可能な割合は屋内・屋外を合せて $63 \%$ となっている。 3 分の 1 以上の最終集積所で収集車の出入りが不可能とい う実態が明らかとなった。屋内設置の割合が高い建物用

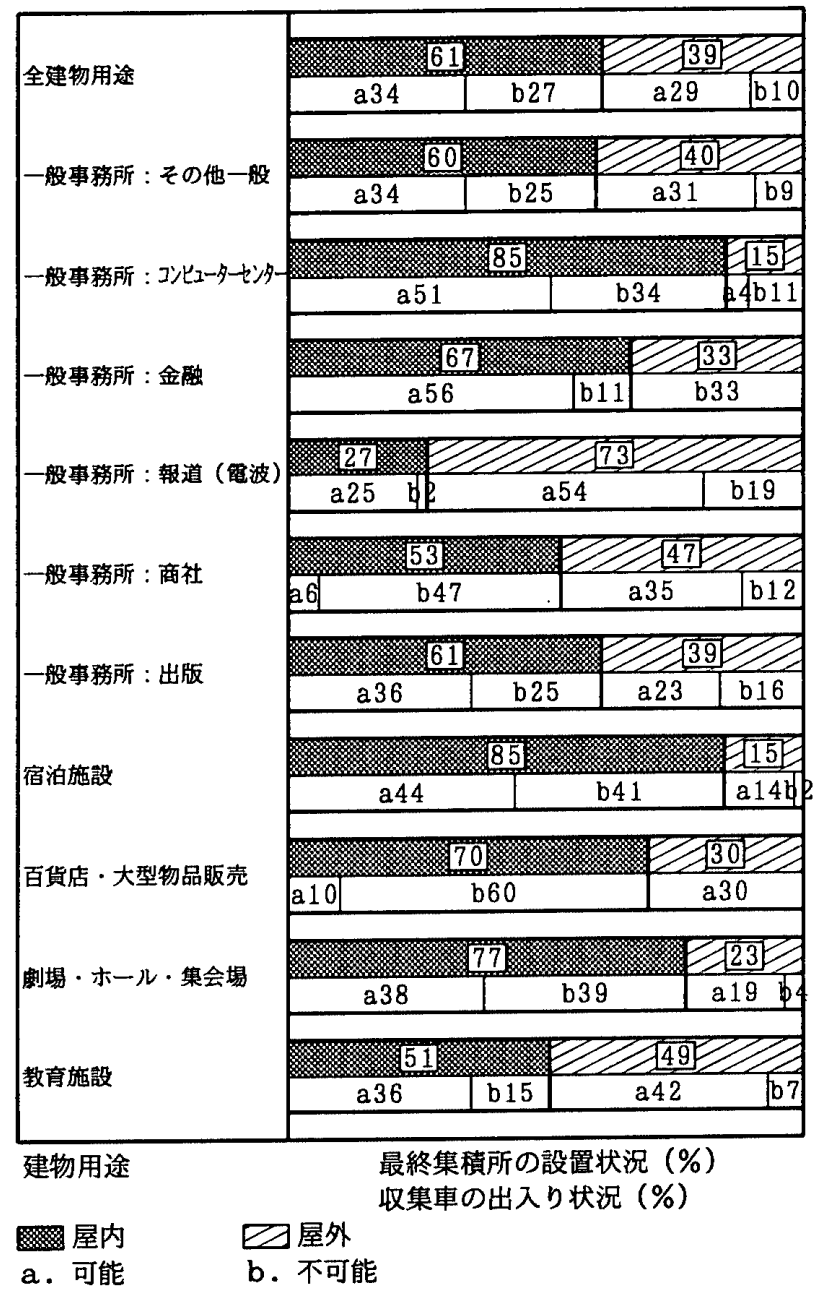

図 6 最終集積所の設置状況（建物用途別） 


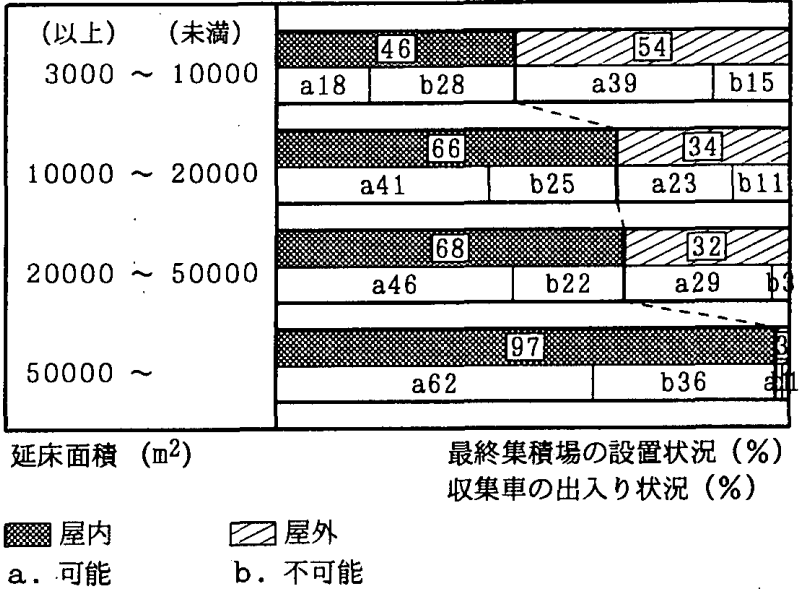

図 7 最終集積所の設置状況（延床面積ランク別）

途としては，「一般事務所 : コンピューターセンタ一」 (85\%)，「宿泊施設」（85\%），「劇場・ホール・集 会場」（77\%）などがあり，一方，低い建物用途には， 「一般事務所：報道（電波）」（27\%）がある。また， 最終集積所への収集車の出入りが不可能とする割合が高 い建物用途として「百貨店・大型物品販売」の60\%があ り，廃棄物発生原単位が $146.9 \mathrm{~g} / \mathrm{m}^{2} \cdot$ 日 $^{11}$ と大きい建物用 途だけに問題があると思われる。

延床面積ランクによる結果からは, 既報 ${ }^{2}$ でもみられ たように延床面積の大きいビルほど，屋内設置の割合が 。 高まる様子かみられる。ただし，規模が大きくなっても， 最終集積所への収集車の出入りについては必ずしも可能 とする割合が増大している訳ではないので，この点に留 意が必要である。.

\section{5.ビルメンテナンス従業員による記述意見について}

ビル内における廃棄物の円滑な収集・運搬・保管・処 理を実現するため，実際に現場での業務に携わっている ビルメンテナンス従業員に対し，ビルの設計に関する意 見・要望の記述を求めた。その主な結果を建物用途こと に表11に要約する。

「一般事務所 : コンピューターセンター」では重量の あるOA用紙の搬出に合せた最終集積所の積み出し口の 設計について，「一般事務所：金融」では重要書類の処 理処分方法の変化に対応できていないビルの状況につい て，「一般事務所 : 報道（電波）」では来館者の多さか ら派生する諸問題について，「宿泊施設」では逨休を考 慮した最終集積所の設計について，「百貨店・大型物品 販売」およひ「飲食店」では嘼芥置場における冷房設備 の必要性についてなど，建物用途に由来する多くの提言 や問題点が示されている。

また，共通する事項としては，荷物用エレベーターの 設置・利用上の問題をはじめとして，水平運搬用台車と 床の仕上げの関係，段差部分へのスロープの設置，最終
集積所に関する館内配置・面積 - 仕切り ・設備・収集車 のアプローチ・雨天対策など, 建築設計計画面での今後 の改善を望む意見か提示されている。

表11 ビルメンテナンス従業員による記述意見

\begin{tabular}{|c|c|}
\hline 建物用途 & 内 \\
\hline $\begin{array}{l}\text { 一般事務所 } \\
\text { : その他一般 }\end{array}$ & 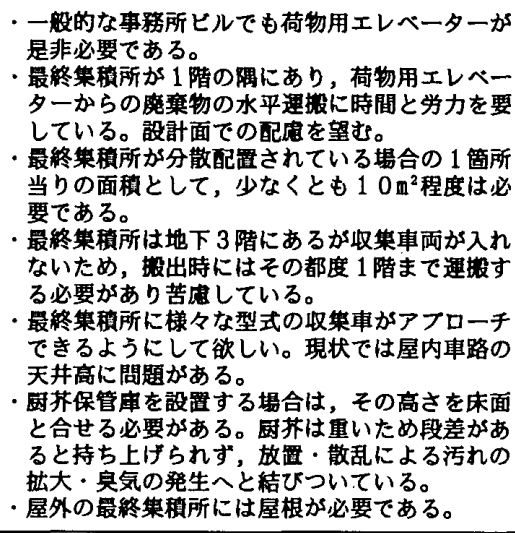 \\
\hline 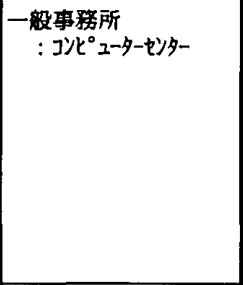 & 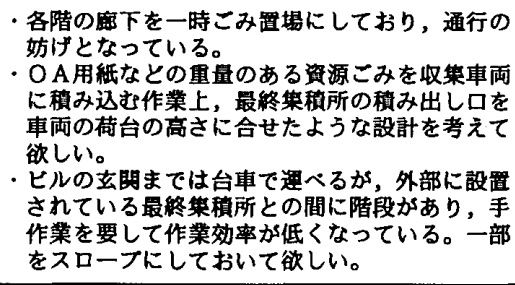 \\
\hline 一般事務所：金熊 & 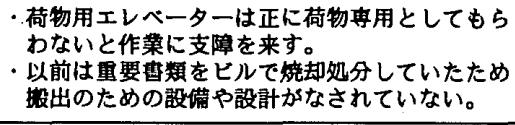 \\
\hline $\begin{array}{l}\text { 一般事蓩所 } \\
\text { : 報道(電波) }\end{array}$ & 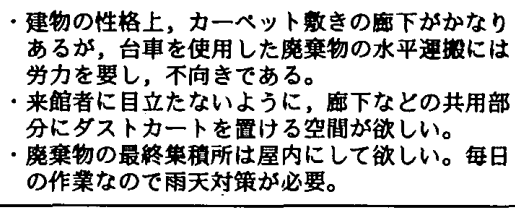 \\
\hline 一般事務所：商社 & 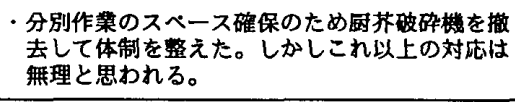 \\
\hline 一般事䇰所：出版 & 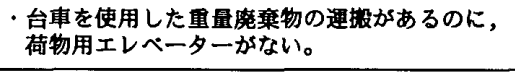 \\
\hline 宿泊施設 & 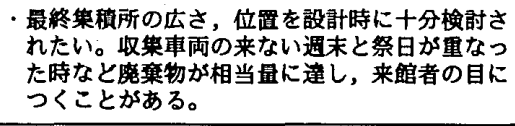 \\
\hline 百貨店 - 大型物品販売 & 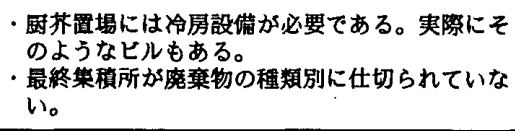 \\
\hline 劇場・ホール・集会場 & 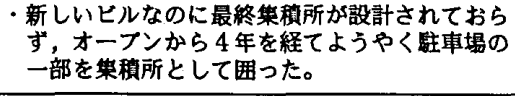 \\
\hline 教育施設 & $\begin{array}{l}\text { ·荷物専用エレベーターが必要。 } \\
\text { 段差には必ずスロープをつけて欲しい。 }\end{array}$ \\
\hline 飲食店 & 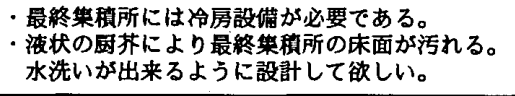 \\
\hline $\begin{array}{l}\text { 一般事務所 } \\
\text { : 報道(活字) }\end{array}$ & 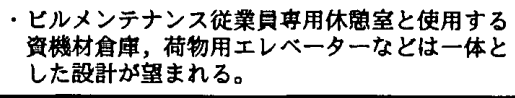 \\
\hline
\end{tabular}




\section{6.まとめ}

本論文は，廃棄物処理の観点からみたビルの建築設計 計画に必要とされる諸事項を検討すべく，ビルメンテナ ンス会社に対して実施したアンケート調查に基づき，回 答の一部として廃棄物の運搬・保管・処理に係わるヒル の諸条件の実態を示したものである。以下に結果をまと める。

（1）一時ごみ置場および最終集積所面積を，夫々，基 準階面積および延床面積に対する比率として，建物用途 ならひに面積ランクに従い提示した。また，最終集積所 の屋内外の設置状況, 収集車の出入りの可否についても まとめた。

（2）廃棄物の垂直運搬に使用されているエレベーター 台数を荷物用・一般用の別に整理するとともに，ビルに 設置されている廃棄物処理設備の現状と処理現場からの 設置希望について明らかにした。

（3）ビルメンテナンス従業員の立場からみたビルの建 築設計計画に関する意見・要望を建物用途別に要約した。 今後は，廃棄物処理の観点から優良と評価される数棟 のビルを対象に，廃棄物の分別収集や運搬経路，最終集 積所の配置なとの分析を進めるとともに，ビル内にけ る廃棄物管理なといわゆるソフト面での取り組みについ ても検討を進める予定である。

\section{謝 辞}

日本建築学会・廃棄物と建築計画特別研究委員会の委 員各位には，委員会活動を通じて有益なる多くのご助言 を晹りました。厚く御礼申し上げます。

付 記

本研究の一部は平成 6 年度・文部省科学研究費補助金 「ビル内廃棄物の収集及び処理の観点からみた建築計画 ・設計資料の作成」によることを付記する。

注 記

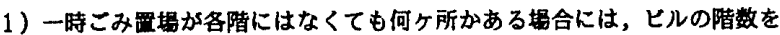
考饥して一時こみ贯掦の面积を各陵に割り振った結果を含んでいる。 また，ヒルメンテナンス従業貝から申告された広さの5段阹評価（仏い，

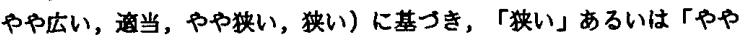
㹟い」場合には，「寀当」とされるまで面箖を割り增している。

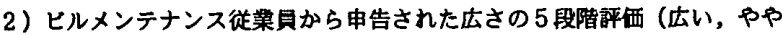

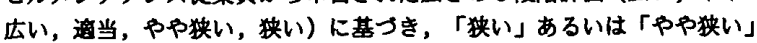
揚合には，「䧟当」とされるまで面校を割り增している。

文 献

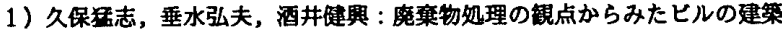

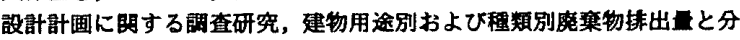
別收集の実焽，日本建栄学会計再系詥文集，第471号，1995.5

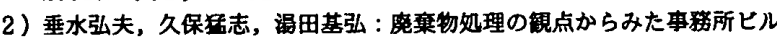
の建筮設即計䧃に開する調查研究，ビルメンテナンス從業員を対象とし た作菜亚境の実態調查，日本建策学会計面系諭文報告集，第 454 号， p p. $113 \sim 121,1993.12$

3) 日本建策学会編: 建策設計资料篓成，第 10 巻，p. $80 ， 185$, $190,1983.7$ 